\title{
APPLICATION OF ASH FOR AMELIORATION OF SALINITY EFFECT IN RICE
}

\author{
A. H. F. Fahim ${ }^{1 *}$, M. A. Kader ${ }^{2}$, M. S. Nahar ${ }^{1}$, M. A. Wadud ${ }^{1}$ and M. A. Islam ${ }^{3}$ \\ ${ }^{1}$ Scientific officer, Spices Research Centre, BARI, Shibganj, Bogra, Bangladesh. \\ ${ }^{2}$ Department of Agronomy, Bangladesh Agricultural University, Mymensingh, Bangladesh. \\ ${ }^{3}$ Senior Scientific officer, Spices Research Centre, BARI, Shibganj, Bogra, Bangladesh. \\ *Corresponding author, E-mail: fahimkbd@gmail.com
}

Keywords: Salinity, ash, stress, rice, BRRI dhan47

\begin{abstract}
Agricultural land use in coastal area covers $53 \%$ and the lands are mostly affected by salinity. Besides, the average yield of rice in these areas is very low due to salinity. Although, BRRI has developed salt registrant rice varieties, the average production can be improved through soil management. Thus, a pot experiment was conducted in the net house of Department of Agronomy, Bangladesh Agricultural University, Mymensingh, during March to August 2010 to investigate the ameliorative effect of ash application on yield and yield attributes of rice under various salinity levels. Rice var. BRRI dhan47 (a salt tolerant variety) was used in the experiment. The sodium chloride induced salinity levels were 20,40,60, 80 and $100 \mathrm{mM} \mathrm{NaCl}$ and the levels of ash applied were 1.5, 3, 4.5 and $6 \mathrm{t} \mathrm{ha}^{-1}$. Results revealed that the different levels of salinity had significant adverse effect on plant height, tillers hill ${ }^{-1}$, panicle hill-1, grains panicle ${ }^{-1}$, 1000-grain weight, grain yield, biological yield and harvest index. All the plants eventually died when they were exposed to salinity level of $40 \mathrm{mM} \mathrm{NaCl}$ or more and could not survive up to maturity. Application of ash enhanced the yield attributes and yield of rice under different salinity levels compared to those without ash. It was concluded that application of ash at the rate of $6 \mathrm{tha}^{-1}$ ameliorated the salinity stress effect on rice yield of BRRI dhan47.
\end{abstract}

\section{Introduction}

In Bangladesh, over 30\% of the net cultivable area lies in the coastal area (Rasel et al, 2013). Out of 2.85 million hectare of coastal and off shore areas, about 0.833 million hectares are arable lands, which constitute about $52.8 \%$ of the net cultivable area in 64 Upzilla of 13 districts (Rasel et al, 2013). This area is largely affected by varying degrees of soil salinity. Agricultural land uses in these areas are very poor and cropping intensity is very low. Salinity largely reduces the yield of rice in the coastal areas of the country mainly in Khulna, Patuakhali, Noakhali and Chittagong districts and in the Island of Bay of Bengal like Bhola, Hatiya and Sandwip (Brammer, 1971).

Salinity level of $4 \mathrm{dsm}^{-1}$ is considered as critical level for rice. However, rice exhibits considerable intra-specific variability in resistance to salinity (Flowers and Yeo, 1981; Maiti et al., 2008).

Application of ash to the soil brought about linear increases in soil aeration, water holding capacity, soil total nitrogen, exchangeable bases and cat ion exchange capacity, but reduced soil bulk density and acidity. Ash supply $\mathrm{Si}$ to the soil which helps the plants to ameliorate the salinity stress (Ma, 2004; Liang et al., 2003). Si is beneficial for growth of many plants under various a biotic (e.g. salt, drought and metal toxicity) and biotic (plant diseases and pests) 
Fahim et al.

stresses (Ma, 2004; Liang et al., 2003). A number of possible mechanisms are reported through which Si may increase salinity tolerance in plants (Liang et al., 2003), including increased plant water status (Romero et al., 2006), immobilization of toxic $\mathrm{Na}^{+}$ion (Liang et al., 2003), reduced $\mathrm{Na}^{+}$uptake in plants and enhanced $\mathrm{K}^{+}$uptake (Tahir et al., 2006; Liang et al., 2005; Yeo et al., 1999) and higher $\mathrm{K}^{+}$: $\mathrm{Na}^{+}$selectivity (Hasegawa et al., 2000). In particular, $\mathrm{Si}$ deposition in the endodermis is proposed to restrict $\mathrm{Na}+$ transport along a "transpirational by pass" route from root to shoot in rice (Gong et al., 2006). Therefore, the present study was under taken to investigate the ameliorative effect of ash on grain yield and yield attributes of rice var. BRRI Dhan47 under various salinity levels.

\section{Materials and Methods}

The experiment was conducted at the net house of the department of Agronomy, Bangladesh Agricultural University (BAU), Mymensingh during the period from March to August, 2010. The experimental site was located at $24^{\circ} \mathrm{N}$ latitude and $94^{\circ} \mathrm{E}$ longitude and 18 meter above sea level. The experimental site belongs to the Agro-ecological Zone of the Old Brahmaputra Floodplain (AEZ 9). The soil was collected within $6 \mathrm{~cm}$ from the top soil. The experimental soil was loamy in texture having a soil $\mathrm{pH}$ value of 6.43 , moderate in organic matter content (Table 1). After collection, the soil was dried in sun and loosened. All the inert matter was removed. The pots were filled up by soil.

Bangladesh Rice Research Institute (BRRI) has developed var. BRRI dhan47 as a salt tolerant variety for boro season as the test crop. This variety can tolerate $12-14 \mathrm{dSm}^{-1}$ salinity at seedling stage and $6 \mathrm{dSm}^{-1}$ salinity for whole life The var. BRRI dhan 47 matures within 150 days after transplanting. It attains a plant height of about $105 \mathrm{~cm}$. The average yield of BRRI dhan 47 is 6.1 tha $^{-1}$ under normal condition and around 4 tha $^{-1}$ in saline (BRRI, 2007). Five level of ash (viz. 0, 1.5, 3, $4.5 \& 6$ tha $^{-1}$ ) and six salinity level (viz. 0, 20, 40, 60, $80 \& 100$ $\mathrm{mM} \mathrm{NaCl}$ ) were used as treatment variables. The experimental was laid put in a factorial Randomized Complete Block Design with five replications. The total number of pots used in this study was 150 (6 x 5 x 5). Seeds of var. BRRI dhan47 were collected from BRRI Gazipur. Seeds were soaked into water in buckets for 24 hours and then taken out of water and incubated in gunny bags for sprouting. Sprouted seeds were sown on 21 March 2010 in the nursery bed.. Plastic pots were selected for the experiment to check the loss of saline water. The size of the pot was $13.5 \mathrm{~cm}$ diameter in top and $30 \mathrm{~cm}$ in height. Each of the pots was filled with $14 \mathrm{~kg}$ of the collected soil and fertilized with urea 25, TSP13, MoP 9 , gypsum 8 and zinc sulphate $1.5 \mathrm{~g} /$ pot. The total amount of TSP, MoP, gypsum and zinc sulphate and one third urea was applied during the final pot preparation and rest of the urea was top dressed at 20 and 40 days after transplanting (DAT). Seedlings were uprooted from nursery bed on 27 April 2010 and transplanted immediately at 3 seedlings hill ${ }^{-1}$. The insecticide Basudin 10 G @ $20 \mathrm{~kg} \mathrm{ha}{ }^{-1}$ were applied to control rice stem borer. The salinity was applied at tillering stage and ash was applied at final pot preparation mixing within $6 \mathrm{~cm}$ of the potted top soil. The roof of the net house was covered with thin polythene sheet to protect the pots from rain water. Harvesting was done on 30 August 2010. Data on plant height, tillers hill ${ }^{-1}$, grains panicle $e^{-1}$, 1000-grain weight, grain yield ( $\left.\mathrm{t} \mathrm{ha}^{-1}\right)$, straw yield ( $\left.\mathrm{tha}^{-1}\right)$ and harvest index (\%) were recorded properly.

Harvest index (HI) was calculated following the formula given below (Kozak et al., 2007)

Grain yield

Harvest index $(\mathrm{HI})=$ 


\section{Application of Ash for Amelioration of Salinity Effect In Rice}

The collected data were analyzed statistically following the analysis of variance (ANOVA) technique and the mean difference were adjudged by Duncan's Multiple Range Test (DMRT) using the statistical computer package program MSTAT-C (Gomez and Gomez, 1984).

Table 1. Initial nutrient status of the potted soil

\begin{tabular}{lc}
\hline Soil Parameters & Content \\
\hline Soil pH & 6.2 \\
Organic carbon (\%) & 1.25 \\
Organic matter (\%) & 1.67 \\
Total nitrogen (\%) & 0.10 \\
Available phosphorus (ppm) & 26.00 \\
Available potassium (me/100 g) & 0.14 \\
Available sulphur & 13.90 \\
\hline
\end{tabular}

Source: Soil science laboratory, Department of Soil Science, BAU, Mymensingh

\section{Results and Discussion}

\section{Effect of salinity levels on yield and yield attributes of rice var. BRRI dhan 47}

Among the different salinity levels, seedlings of $0 \mathrm{mM} \mathrm{NaCl}$ and $20 \mathrm{mM} \mathrm{NaCl}$ were survive up to maturity but the seedlings of $40,60,80 \& 100 \mathrm{mM} \mathrm{NaCl}$ were died (Table 2). The tallest plant $(100 \mathrm{~cm})$, higher number of tillers hill ${ }^{-1}(24)$ and panicle hill ${ }^{-1}(21)$ was recorded from control treatment

$(0 \mathrm{mM} \mathrm{NaCl})$ whereas the shortest plant $(97 \mathrm{~cm})$, lower number of tillers hill ${ }^{-1}(22)$ and panicles hill $^{-1}$ (19) was recorded from $20 \mathrm{mM} \mathrm{NaCl}$ salinity level. Hasanuzzaman et al. (2009) reported that the plant height decreased with increasing salinity level. Zeng and Shannon (2000) stated that there were significant reductions in tiller number at higher salt levels.

The higher number of grains panicle 1 (94) and 1000-grain weight $(25.67 \mathrm{~g})$ was recorded in control treatment $(0 \mathrm{mM} \mathrm{NaCl})$ whereas the lower number of grains panicle ${ }^{-1}(93)$ and 1000 grains weight $(24.67 \mathrm{~g})$ was recorded when applied $20 \mathrm{mM} \mathrm{NaCl}$ salinity level. Islam (2004) reported that number of grains panicle ${ }^{-1}$ decreased with increased salinity levels. Also Mortazainezhad et al. (2006) was observed that 1000-grains weight was negatively influenced by different salinity levels in the rice cultivars.

Table 2. Effect of salinity on yield and yield attributes of rice var. BRRI dhan47

\begin{tabular}{lcccccccc}
\hline $\begin{array}{l}\text { Salinity } \\
\text { levels }\end{array}$ & $\begin{array}{c}\text { Plant } \\
\text { height } \\
\text { (cm) }\end{array}$ & $\begin{array}{c}\text { Tillers } \\
\text { hill }{ }^{-1} \\
\text { (no.) }\end{array}$ & $\begin{array}{c}\text { Panicle } \\
\text { hill }^{-1}\end{array}$ & $\begin{array}{c}\text { Grains } \\
\text { panicle } \\
\text { (no.) }\end{array}$ & $\begin{array}{c}1000- \\
\text { grain } \\
\text { weight (g) }\end{array}$ & $\begin{array}{c}\text { Grain } \\
\text { yield } \\
\left(\mathrm{t} \mathrm{ha}^{-1}\right)\end{array}$ & $\begin{array}{c}\text { Straw } \\
\text { yield } \\
\left(\mathrm{t} \mathrm{ha}^{-1}\right)\end{array}$ & $\begin{array}{c}\text { Harvest } \\
\text { Index } \\
(\%)\end{array}$ \\
\hline $\mathrm{S}_{0}$ & $100 \mathrm{a}$ & $24 \mathrm{a}$ & $21 \mathrm{a}$ & $94 \mathrm{a}$ & $25.67 \mathrm{a}$ & $4.33 \mathrm{a}$ & $7.22 \mathrm{a}$ & $33.17 \mathrm{a}$ \\
$\mathrm{S}_{1}$ & $97 \mathrm{~b}$ & $22 \mathrm{~b}$ & $19 \mathrm{~b}$ & $93 \mathrm{~b}$ & $24.67 \mathrm{~b}$ & $4.02 \mathrm{~b}$ & $5.98 \mathrm{~b}$ & $33.15 \mathrm{~b}$ \\
$\mathrm{~S}_{2}$ & - & - & - & - & - & - & - & - \\
$\mathrm{S}_{3}$ & - & - & - & - & - & - & - & - \\
$\mathrm{S}_{4}$ & - & - & - & - & - & - & - & - \\
$\mathrm{S}_{5}$ & - & - & - & - & - & - & - & - \\
\hline $\mathrm{LSD}(0.05)$ & 1.49 & 0.51 & 0.72 & 3.66 & 0.35 & 0.08 & 0.21 & 0.98 \\
$\mathrm{CV}(\%)$ & 8.10 & 11.89 & 19.48 & 20.70 & 9.59 & 11.78 & 16.85 & 15.80 \\
\hline
\end{tabular}

$\mathrm{S}_{0}=0 \mathrm{mM} \mathrm{NaCl}, \mathrm{S}_{1}=20 \mathrm{mM} \mathrm{NaCl}, \mathrm{S}_{2}=40 \mathrm{mM} \mathrm{NaCl}, \mathrm{S}_{3}=60 \mathrm{mM} \mathrm{NaCl}, \mathrm{S}_{4}=80 \mathrm{mM} \mathrm{NaCl}$ and $\mathrm{S}_{5}=100 \mathrm{mM} \mathrm{NaCl}$. 
Fahim et al.

The higher grain yield (4.33 $\left.\mathrm{t} \mathrm{ha}^{-1}\right)$, straw yield $\left(7.22 \mathrm{t} \mathrm{ha}^{-1}\right)$ and harvest Index (33.17\%) was recorded from control treatment $(0 \mathrm{mM} \mathrm{NaCl})$. On the other hand, the lower grain yield $(4.02 \mathrm{t}$ $\left.\mathrm{ha}^{-1}\right)$, straw yield $\left(5.98 \mathrm{t} \mathrm{ha}^{-1}\right)$ and harvest Index (33.15\%) was recorded from the salinity level $20 \mathrm{mM} \mathrm{NaCl}$. Sexcion et al. (2009) reported that grain yield decreased with increasing salinity levels. The seedlings of 40,60, $80 \& 100 \mathrm{mM} \mathrm{NaCl}$ were died after salt application.

\section{Effect of ash on yield and yield attributes of var. BRRI dhan47}

Different level of ash had significant effect on yield and yield attributes of BRRI dhan47 (Table 3). The maximum plant $(101 \mathrm{~cm})$ was recorded from 6 tha ${ }^{-1}$ ash which was identical to $4.5 \mathrm{t}$ $\mathrm{ha}^{-1}$ ash whereas the shortest plant $(95 \mathrm{~cm})$ from the control treatment. Ogbodo et al. (2009) stated that plant height increase with the increasing ash level. The higher number of tillers hill ${ }^{-1}$ (26) was recorded from the treatment $6 \mathrm{t} \mathrm{ha}^{-1}$ ash which was identical to $4.5 \mathrm{t} \mathrm{ha}^{-1}$ ash (24) whereas the lower number of tillers hill ${ }^{-1}(20)$ from control.

Higher number of panicles hill-1 ${ }^{-1}$ (23), grains panicle ${ }^{-1}$ (100) and 1000-grain weight (26.98 g) was recorded from the treatment $6 \mathrm{t} \mathrm{ha}^{-1}$ ash whereas the lower number of panicle hill-1 (15), grains panicle ${ }^{-1}(83)$ and 1000 - grains weight $(22.41 \mathrm{~g})$ from the control.. The maximum grain yield $\left(4.46 \mathrm{t} \mathrm{ha}^{-1}\right)$ was recorded from $6 \mathrm{t} \mathrm{ha}^{-1}$ ash, which was identical to the treatment $4.5 \mathrm{t}$ $\mathrm{ha}^{-1}$ ash (4.45 t ha-1) followed by $3 \mathrm{t} \mathrm{ha}^{-1}$ ash $\left(4.20 \mathrm{t} \mathrm{ha}{ }^{-1}\right)$. The lowest grain yield $\left(3.70 \mathrm{t} \mathrm{ha}^{-1}\right)$ was recorded from the control treatment. Similarly, Subramoniam and Chandrasekaran (2005); Sudhakar et al. (2004) stated that the grain yield increased with the increasing level of ash. The highest straw yield $\left(6.93 \mathrm{t} \mathrm{ha}^{-1}\right)$ and harvest index (35.40\%) was recorded from the treatment 6 $\mathrm{t} \mathrm{ha} \mathrm{a}^{-1}$ ash whereas the lowest straw yield $\left(6.19 \mathrm{t} \mathrm{ha}^{-1}\right)$ and harvest index (31.17\%) from control treatment $\left(0 \mathrm{t} \mathrm{ha}^{-1}\right.$ ash).

Table 3. Effect of ash on yield and yield attributes of rice var. BRRI dhan47

\begin{tabular}{lcccccccc}
\hline $\begin{array}{c}\text { Levels of } \\
\text { ash }\end{array}$ & $\begin{array}{c}\text { Plant } \\
\text { height } \\
\text { (cm) }\end{array}$ & $\begin{array}{c}\text { Tillers } \\
\text { hill } \\
\text { (no.) }\end{array}$ & $\begin{array}{c}\text { Panicle } \\
\text { hill }^{-1}\end{array}$ & $\begin{array}{c}\text { Grains } \\
\text { panicle } \\
\text { (no.) }\end{array}$ & $\begin{array}{c}\text { 1000-grain } \\
\text { weight }(\mathrm{g})\end{array}$ & $\begin{array}{c}\text { Grain } \\
\text { yield } \\
\text { tha }^{-1} \text { ) }\end{array}$ & $\begin{array}{c}\text { Straw } \\
\text { yield } \\
\text { (tha }^{-1} \text { ) }\end{array}$ & $\begin{array}{c}\text { Harvest } \\
\text { index } \\
(\%)\end{array}$ \\
\hline $\mathrm{A}_{0}$ & $95 \mathrm{~b}$ & $20 \mathrm{~d}$ & $15 \mathrm{~b}$ & $83 \mathrm{~b}$ & $22.41 \mathrm{c}$ & $3.70 \mathrm{c}$ & $6.15 \mathrm{a}$ & $31.17 \mathrm{~b}$ \\
$\mathrm{~A}_{1}$ & $97 \mathrm{ab}$ & $22 \mathrm{~cd}$ & $17 \mathrm{~b}$ & $93 \mathrm{ab}$ & $24.41 \mathrm{~b}$ & $4.02 \mathrm{bc}$ & $6.38 \mathrm{a}$ & $31.8 \mathrm{ab}$ \\
$\mathrm{A}_{2}$ & $98 \mathrm{ab}$ & $23 \mathrm{bc}$ & $21 \mathrm{a}$ & $97 \mathrm{ab}$ & $23.43 \mathrm{ab}$ & $4.20 \mathrm{ab}$ & $6.70 \mathrm{a}$ & $32.04 \mathrm{ab}$ \\
$\mathrm{A}_{3}$ & $101 \mathrm{a}$ & $24 \mathrm{ab}$ & $22 \mathrm{a}$ & $99 \mathrm{a}$ & $26.62 \mathrm{a}$ & $4.45 \mathrm{a}$ & $6.84 \mathrm{a}$ & $35.34 \mathrm{a}$ \\
$\mathrm{A}_{4}$ & $101 \mathrm{a}$ & $26 \mathrm{a}$ & $23 \mathrm{a}$ & $100 \mathrm{a}$ & $26.98 \mathrm{a}$ & $4.46 \mathrm{a}$ & $6.93 \mathrm{a}$ & $35.40 \mathrm{a}$ \\
\hline LSD $(0.05)$ & 1.36 & 0.47 & 0.66 & 3.34 & 0.32 & 0.07 & 0.19 & 0.89 \\
$\mathrm{CV}(\%)$ & 8.10 & 11.89 & 19.48 & 20.70 & 9.59 & 11.78 & 16.85 & 15.80 \\
\hline
\end{tabular}

$\mathrm{A}_{0}=$ Control, $\mathrm{A}_{1}=1.5 \mathrm{tha}^{-1}, \mathrm{~A}_{2}=3 \mathrm{tha}{ }^{-1}, \mathrm{~A}_{3}=4.5 \mathrm{t} \mathrm{ha}^{-1}, \mathrm{~A}_{1}=6 \mathrm{tha}^{-1}$

\section{Interaction of ash and salinity levels on yield and yield attributes of rice var. BRRI dhan47}

The interaction effect of ash and salinity levels had significant effect on the yield and yield attributes of rice var. BRRI dhan47 (Table 4). The tallest plant $(102 \mathrm{~cm})$ was recorded from the treatment combination of $0 \mathrm{mM} \mathrm{NaCl} \times 6 \mathrm{t} \mathrm{ha}^{-1}$ ash which was identical to $0 \mathrm{mM} \mathrm{NaCl} \times 4.5 \mathrm{t}$ $\mathrm{ha}^{-1}$ ash $(102 \mathrm{~cm})$ whereas, the shortest plant $(92 \mathrm{~cm})$ was recorded when no ash was applied with salinity level $20 \mathrm{mM} \mathrm{NaCl}$. The number of tillers hill-1 was higher (26) in the treatment combination of $0 \mathrm{mM} \mathrm{NaCl} \times 6 \mathrm{t} \mathrm{ha}^{-1}$ ash which was identical to $0 \mathrm{~m} \mathrm{M} \mathrm{NaCl} \times 4.5 \mathrm{t} \mathrm{ha}^{-1}$ ash (25) followed by $20 \mathrm{~m} \mathrm{M} \mathrm{NaCl} \times 6 \mathrm{t} \mathrm{ha}^{-1}$ ash (25) whereas, lower (19) in the treatment

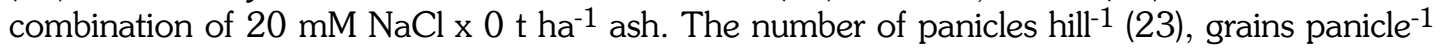


Application of Ash for Amelioration of Salinity Effect In Rice

(101) and 1000-grain weight $(21.36 \mathrm{~g})$ was higher in $0 \mathrm{mM} \mathrm{NaCl} \times 6 \mathrm{t} \mathrm{ha}^{-1}$ ash and lower number of panicles hill-1 ${ }^{-1}$ (15), grains panicle ${ }^{-1}$ (76) and 1000-grain weight (17.20) was obtained from $20 \mathrm{mM} \mathrm{NaCl} \times 0 \mathrm{t} \mathrm{ha}^{-1}$ ash.

The maximum grain yield $\left(4.54 \mathrm{t} \mathrm{ha}^{-1}\right)$ was recorded from the treatment combination of $0 \mathrm{mM}$ $\mathrm{NaCl} \times 6 \mathrm{t} \mathrm{ha}^{-1}$ ash which was identical to $0 \mathrm{mM} \mathrm{NaCl} \times 4.5 \mathrm{t} \mathrm{ha}^{-1}$ ash $\left(4.52 \mathrm{t} \mathrm{ha}^{-1}\right)$ followed by $20 \mathrm{mM} \mathrm{NaCl} \times 6 \mathrm{t} \mathrm{ha}^{-1}$ ash $\left(4.39 \mathrm{t} \mathrm{ha}^{-1}\right)$. The lowest grain yield $\left(3.49 \mathrm{t} \mathrm{ha}^{-1}\right)$ was obtained from the treatment combination $20 \mathrm{mM} \mathrm{NaCl} \times 0$ t ha-1 ash.

The harvest index was higher (37.32\%) in the treatment combination $20 \mathrm{mM} \mathrm{NaCl} \times 4.5 \mathrm{t}$

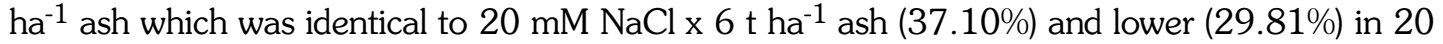
$\mathrm{mM} \mathrm{NaCl} \times 0$ t ha ${ }^{-1}$ ash.

Table 4. Interaction of ash and salinity levels on yield and yield attributes of rice vr. BRRI dhan 47

\begin{tabular}{|c|c|c|c|c|c|c|c|c|}
\hline Interactions & $\begin{array}{l}\text { Plant } \\
\text { height } \\
(\mathrm{cm})\end{array}$ & $\begin{array}{l}\text { Tillers } \\
\text { hill }^{-1} \\
\text { (no.) }\end{array}$ & $\begin{array}{c}\text { Panicle } \\
\text { hill }^{-1}\end{array}$ & $\begin{array}{c}\text { Grains } \\
\text { panicle }{ }^{-1} \\
\text { (no.) }\end{array}$ & $\begin{array}{l}\text { 1000-grain } \\
\text { weight (g) }\end{array}$ & $\begin{array}{c}\text { Grain } \\
\text { yield } \\
\left(\text { tha }^{-1}\right)\end{array}$ & $\begin{array}{l}\text { Straw yield } \\
\left(\text { tha }^{-1}\right)\end{array}$ & $\begin{array}{l}\text { Harvest } \\
\text { Index (\%) }\end{array}$ \\
\hline $\mathrm{A}_{0} \mathrm{~S}_{0}$ & $98 a b c$ & $21 d$ & $15 \mathrm{~d}$ & $91 b$ & & $3.94 \mathrm{~cd}$ & & 1004 \\
\hline$A_{0} S_{1}$ & $92 d$ & $19 e$ & $15 d$ & $76 c$ & $22.36 e$ & $3.49 e$ & $29.81 e$ & $29.81 e$ \\
\hline $\mathrm{A}_{1} \mathrm{~S}_{0}$ & $98 a b c$ & $22 \mathrm{~d}$ & $20 b c$ & $93 a b$ & & $4.27 b$ & & $4 b c$ \\
\hline $\mathrm{A}_{1} \mathrm{~S}_{1}$ & $95 \mathrm{~cd}$ & $21 d$ & $15 \mathrm{~d}$ & $94 a b$ & 24 & $3.78 \mathrm{~d}$ & & $6 \mathrm{de}$ \\
\hline $\mathrm{A}_{2} \mathrm{~S}_{0}$ & 99ab & $25 b c$ & $23 a$ & $99 a b$ & $26.00 b$ & $4.35 \mathrm{ab}$ & 33.0 & $1 b c$ \\
\hline $\mathrm{A}_{2} \mathrm{~S}_{1}$ & $97 b c$ & $22 \mathrm{~d}$ & $19 c$ & $95 a b$ & 24. & $4.04 \mathrm{c}$ & 31.0 & $5 \mathrm{cde}$ \\
\hline $\mathrm{A}_{3} \mathrm{~S}_{0}$ & $102 a$ & $25 a b$ & $22 a$ & $101 a$ & & $4.52 \mathrm{a}$ & & $3 b c$ \\
\hline $\mathrm{A}_{3} \mathrm{~S}_{1}$ & $101 \mathrm{ab}$ & $24 c$ & $21 \mathrm{ab}$ & $98 \mathrm{ab}$ & $25.70 b c$ & $4.38 \mathrm{ab}$ & 37 & $2 a$ \\
\hline $\mathrm{A}_{4} \mathrm{~S}_{0}$ & $102 \mathrm{a}$ & $26 a$ & $23 a$ & & 27 & $4.54 a$ & & \\
\hline $\mathrm{A}_{4} \mathrm{~S}_{1}$ & $101 \mathrm{ab}$ & $25 a b c$ & $22 \mathrm{a}$ & $98 \mathrm{ab}$ & $26.23 b$ & $4.39 \mathrm{ab}$ & $37.10 \mathrm{a}$ & $10 \mathrm{a}$ \\
\hline & 0.61 & 0.21 & 0.29 & 1.98 & & 0.04 & & \\
\hline $\mathrm{CV}(\%)$ & 8.10 & 11.89 & 19.48 & 20.70 & 9.59 & 11.78 & 15.80 & 15.80 \\
\hline
\end{tabular}

$\mathrm{A}_{0}=$ Control, $\mathrm{A}_{1}=1.5$ tha $^{-1}, \mathrm{~A}_{2}=3$ tha $^{-1}, \mathrm{~A}_{3}=4.5$ tha $^{-1}, \mathrm{~A}_{1}=6$ tha ${ }^{-1}, \mathrm{~S}_{0}=0 \mathrm{mM} \mathrm{NaCl}$ and $\mathrm{S}_{1}=20 \mathrm{mM}$ $\mathrm{NaCl}$.

\section{Conclusion}

It can be concluded that, application of ash ameliorated the salinity stress effect on rice yield. It was also found that, the salt tolerance level of rice var. BRRI dhan 47 was $20 \mathrm{mM} \mathrm{NaCl}$ when cultivated with 6 ton ha ${ }^{-1}$ ash .

\section{References}

Brammer, H. 1971. Agricultural development possibilities in Bangladesh. Soil Survey Project Technical Report No. 2. FAO, Rome.

Flowers, T. J. and A. R. Yeo. 1981. Ion relations of plants under drought and salinity. Aust. J. Plant Physiol. 13: 75-91.

Gomez, H. C. and A. A. Gomez. 1984. Statistical Procedures for Agric. Res., John Wiley and Sons. New York, p. 680. Gong H. J., D. P. Randall and T. J. Flowers. (2006). Silicon deposition 
Fahim et al.

in the root reduces sodium uptake in rice (Oryza sativa L.) seedlings by reducing bypass flow. Plant Cell Environ. 29: 1970-1979.

Hasanuzzaman, M., M. Fujita, M. N. Islam, K. U. Ahamed and K. Nahar. 2009. Performance of four irrigated rice varieties under different levels of salinity stress. Int. J. Integrative Biol. 6(2): 85-90.

Hasegawa, P., R. A. Bressan, J. K. Zhu and H. J. Bohnert. 2000. Plant cellular and molecular responses to high salinity. Annu. Rev. Plant Mol. Biol. 51: 463-499.

Kozak, M., S. Samborski, M. S. Kang and J. Rozbicki. 2007. Applying statistics for nonsequential yield component analysis. Plant, Soil and Environment. 53(10): 456463.

Liang, Y. C., W. Q. Zhang, J. Chen and R. Ding. 2005. Effect of silicon on $\mathrm{H}^{+}-$ATPase and $\mathrm{H}^{+-}$ PPase activity, fatty acid composition and fluidity of tonoplast vesicles from roots of saltstressed barley (Hordeum vulgare L.). J. Environ. Exp. Bot. 53: 29-37.

Liang, Y. C., Q. Chen, Q. Liu, W. Zhang and R. Ding. 2003. Effects of silicon on salinity tolerance of two barley cultivars. J. Plant Physiol. 160: 1157-1164.

Ma, J. F. 2004. Role of silicon in enhancing the resistance of plants to biotic and abiotic stresses. J. Soil Sci. Plant Nutrition. 50: 11-18.

Maiti, R., P. Vidyasagar and P. P. Banerjee. 2008. Characterization of salinity tolerance in rice ( Oryza sativa L.) genotypes at the germination and seedling stages. Acta Agronomica Hungarica 56(2): 139-147

Mortazainezhad, F., R. Khavarinejad and M. Emami. 2006. Study of some parameters of yield and proline in rice plants under $\mathrm{NaCl}$ salinity stress. J. New. Agric. Sci. 2(4): 93-98.

Ogbodo, E. N. 2009. Changes in the Properties of an Acid Soil Amended with Burnt Rice Husk and the Effect on the Growth and Yield of Pepper at Abakaliki South Eastern Nigeria, Am. Eurasian J. Sustain. Agric. 3(3): 579-586.

Rasel, H. M., M. R. Hasan, B. Ahmed and M. S. U. Miah. 2013. Inves tigation of soil and water salinity, its effect on crop production and adaptation strategy. International J. of Water Res. and Env. Eng. 5(8): 475-481.

Subramoniam, S. R. and A. Chandrasekaran. 2005. Chemical properties of lateritic soil and yield of rice as influenced by addition of fly ash. International Rice Res. Notes. Int. Rice Res. Inst. Manila, Philippines. 30(1): 35-37.

Sudhakar, P. C., J. P. Singh and S. Kalyan. 2004. Effect of silicon sources and fertility levels on transplanted rice. International Rice Res. Notes. Int. Rice Res. Inst. (IRRI), Manila, Philippines. 29(2): 61-63.

Suzuki S., J. F. Ma, N. Yamamoto, T. Hattori, M. Sakamoto and T. Umezawa. 2012. Silicon deficiency promotes lignin accumulation in rice. Plant Biotechnol. 29: 391-394.

Tahir, M., A. Rahmatullah, T. Aziz, M. Ashraf, S. Kanwal and A. Muhammad. 2006. Beneficial effects of silicon in wheat under salinity stress-pot culture. Pak. J. Bot. 38: 1715-1722.

Yeo, A. R., S. A. Flowers, G. Rao, K. Welfare, N. Senanayake and T. J. Flowers. 1999. Silicon reduces sodium uptake in rice (Oryza sativa L.) in saline conditions and this is accounted for by reduction in transpirational bypass flow. Plant cell Environ. 22: 559-565.

Zeng. L. H. and M. C. Shannon. 2000. Salinity effects on seedling growth and yield components of rice. Crop Sci. Society America, Madison, USA. 40(4): 996-1003. 